\title{
Applications of Gypsum and Ammonium Sulfate Change Soil Chemical Properties of a Salt-Affected Agricultural Soil
}

\author{
Guilherme Bossi Buck ${ }^{1}$, Gustavo Franco de Castro ${ }^{1,2}$, Edson Marcio Mattiello ${ }^{2} \&$ Lincoln Zotarelli $^{1}$ \\ ${ }^{1}$ Horticultural Sciences Department, University of Florida, Gainesville, FL, USA \\ ${ }^{2}$ Department of Soils, Universidade Federal de Viçosa, Viçosa, MG, Brazil \\ Correspondence: Lincoln Zotarelli, Horticultural Sciences Department, University of Florida, 1241 Fifield Hall, \\ Gainesville, FL 32611, USA. Tel: 1-352-273-4949. E-mail: lzota@ufl.edu
}

$\begin{array}{lc}\text { Received: May 6, } 2020 & \text { Accepted: June 3, } 2020 \quad \text { Online Published: June 15, } 2020 \\ \text { doi:10.5539/jas.v12n7p1 } & \text { URL: https://doi.org/10.5539/jas.v12n7p1 }\end{array}$

The research is financed by University of Florida, Horticultural Sciences Department.

\begin{abstract}
Irrigation water with high electrical conductivity (EC) compromises the sustainability of agricultural soils. Calcium sulfate (CS) or gypsum is commonly used on removal of soluble ions such as sodium (Na), however, large applications of CS can affect soil $\mathrm{pH}, \mathrm{EC}$, and nutrient availability to plants. The objective of this study was to investigate the effects of CS and ammonium sulfate (AS) rates on the soil $\mathrm{pH}, \mathrm{EC}$, and exchangeable cations in a salt-affected agricultural soil. Samples from the 0-20 cm soil depth layer were collected from an agricultural soil reported to have low potato yield due to high EC irrigation water. Soil was incubated with rates ranging from 0 to $4000 \mathrm{~kg} \mathrm{ha}^{-1}$ of CS and 0 to $600 \mathrm{~kg} \mathrm{ha}^{-1}$ of nitrogen (N) using AS. The treated soil was incubated for $60 \mathrm{~d}$ at $25{ }^{\circ} \mathrm{C}$ and moisture was maintained at $60 \%$ of soil field capacity. After incubation, the soil was analyzed for $\mathrm{pH}, \mathrm{EC}, \mathrm{Na}$, manganese $(\mathrm{Mn})$, and zinc $(\mathrm{Zn})$. Increasing rates of $\mathrm{CS}$ resulted in a small decrease in soil $\mathrm{pH}$ and a significant linear increase in soil EC, while the application of AS linearly reduced the soil $\mathrm{pH}$ and quadratically increased soil EC. The application rate of $200 \mathrm{~kg} \mathrm{ha}^{-1}$ of $\mathrm{N}$ as AS resulted in a decrease of soil $\mathrm{pH}$ from 5.9 to 5.2 , while the EC increased from 1.3 to $3.0 \mathrm{dS} \mathrm{m}^{-1}$. Extractable $\mathrm{Na}$ increased linearly with the application of AS due to its effect on the soil $\mathrm{pH}$. The soil extractable $\mathrm{Mn}$ and $\mathrm{Zn}$ were not affected by the application of CS. Applications of AS resulted in a linear increase in soil extractable Mn and $\mathrm{Zn}$ concentrations, respectively. Results from this incubation study suggest that the use of large rates of CS for consecutive years may further impair soil conditions for cropping in areas with high EC in the irrigation water.
\end{abstract}

Keywords: base saturation, cations, potato, saltwater intrusion, Solanum tuberosum, sandy soil, sodium, soil salinity

\section{Introduction}

Groundwater is an important natural resource for domestic, agricultural, industrial, and public use in Florida as well as other parts of the world. The soils in northeast Florida were formed primarily from marine deposits and the proximity of the coastal areas leads the Floridian Aquifer System to be frequently intruded with saltwater (Frazee Jr. \& McClaugherty, 1979). Saltwater intrusion is defined as the movement of saline water into freshwater aquifers, which can lead to contamination of freshwater sources. Saltwater intrusion occurs naturally to some degree in most coastal aquifers, owing to the hydraulic connection between groundwater and sea water. Because saltwater has a higher mineral content than fresh water, it is denser and has a higher water pressure with high EC. Activities like intensive groundwater pumping for public, industrial, and agricultural consumption can exacerbate saltwater intrusion (Barlow, 2003; Xiao et al., 2019). Particularly in northern St. Johns County, in Florida, the water type from the Upper Floridian Aquifer has high concentrations of calcium $\left(\mathrm{Ca}^{2+}\right)$, magnesium $\left(\mathrm{Mg}^{2+}\right)$ and sulfate $\left(\mathrm{SO}_{4}{ }^{2-}\right)$ and the presence of sodium chloride $(\mathrm{NaCl})$ represents a mixing of saltwater with fresh aquifer water (Spechler, 1994).

The counties of St. Johns, Putnam and Flagler in northeast Florida are important agricultural production areas of winter/spring vegetables and potato (Solanum tuberosum L.). Seepage irrigation, also called subirrigation, has been the predominant irrigation method for vegetable production in Florida (Dukes et al., 2010). The presence of 
a shallow impermeable soil layer between 1 to $3 \mathrm{~m}$ below the soil surface allows growers to control the water table level for irrigation by pumping fresh groundwater in the fields. A series of furrows and ditches assist with the water distribution. A significant volume of groundwater is required to raise and maintain the water table level just below the plant root zone (Ferreira et al., 2017; Liao et al., 2016). After rainfall, generally the water table level is receded by draining the excess water offsite (da Silva et al., 2018).

Saltwater intrusion has severely impacted agriculture in northeast Florida. In recent years, there has been an increase in salt content in the irrigation wells, which might be attributed to low rainfall years and increasing water pumping for crop irrigation (Yarney, 2017). The problem is exacerbated with the use of seepage irrigation that applies large volumes of water with high salt content. Salts tend to accumulate in the soil profile above the impermeable soil layer, causing severe reduction in vegetable productivity in dry years. In the past 8 years, most of the growers have abandoned fertilizer broadcasting practices for more efficient application techniques such as banding of granular fertilizer or localized application of liquid fertilizers using knife applicator. Fertilizers with a high salt index can lead to an increase in soil EC with cations such as $\mathrm{Ca}^{2+}, \mathrm{Mg}^{2+}$ and sodium $\left(\mathrm{Na}^{+}\right)$and anions such as chloride $\left(\mathrm{Cl}^{-}\right), \mathrm{SO}_{4}{ }^{2-}$, bicarbonate $\left(\mathrm{HCO}^{3-}\right)$, and carbonate $\left(\mathrm{CO}_{3}{ }^{2-}\right)$ (Dunlop et al., 2019; Havlin et al., 1999; Mao et al., 2016; Vargas et al., 2015).

The use of CS on potato fields has become very popular among growers in recent years due to its low cost. In northeast Florida, applications of $\mathrm{Ca}$ are primarily used to minimize some potato tuber disorders like brown center, which are associated with Ca deficiency (Palta, 1996). Although the benefits of CS on tuber yield, tuber specific gravity, hollow heart or chip color were not confirmed to justify a routine application of CS on potato (Silva et al., 1991), CS has been periodically applied by growers. Liao et al. (2015) surveyed 32 private potato farms in northeast Florida and reported annual CS application rates between 896-2240 $\mathrm{kg} \mathrm{ha}^{-1}$, despite the fact that the soil Ca concentrations in the 0-20 cm soil depth layer on those same farms ranged between 374-3362 mg $\mathrm{kg}^{-1}$ (Mehlich-1 extractant), levels in which were classified as "very high" (Hochmuth et al. 2018; Liu et al., 2018). In other parts of the country severely affected by soil salinity, CS is used to promote the exchange of $\mathrm{Na}^{+}$ by $\mathrm{Ca}^{2+}$ in the soil (Mao et al., 2016). Once $\mathrm{Na}^{+}$is available in the soil solution, leaching practices can be applied to decrease the $\mathrm{Na}^{+}$content in the root zone (Sonon et al., 2015). However, in northeast Florida due to the shallow impermeable soil layer and high water table, leaching practices are less efficient than well-drained soils or areas with subsurface drain tile. Thus, management practices to prevent the introduction of salts in the field such as using low salt index fertilizers, avoiding excessive fertilizer application rates, and reducing irrigation water application have all become very important to maintain the sustainability of vegetable production in the region.

Sulfur (S) deficiency can occur in very sandy soils with low soil organic matter, especially following the continued use of sulfur-free fertilizer (Liu et al., 2018). The use of AS may be an alternative to supply S, and at same time, minimize $\mathrm{N}$ leaching compared to nitrate fertilizer sources. In fact, fertilizer blends used by potato growers may contain up to $24 \%$ of AS as a source of N. Although AS is a source for N and S for plants, AS can drastically reduce soil $\mathrm{pH}$ due to its acidifying power (Wang et al., 2018). Hart et al. (2013) stated that AS produces up to twice as much hydrogen $\left(\mathrm{H}^{+}\right)$in soil compared to urea. Another possible disadvantage in using this source of $\mathrm{N}$ is the increase in soil EC. The application of $\mathrm{N}$ as AS has the potential to increase soil EC by 40 to $80 \%$ more than the same amount of $\mathrm{N}$ applied as urea (Vargas et al., 2015). According to Machado et al. (2014), for each gram per liter of AS applied in the soil, there is a $2 \mathrm{dS} \mathrm{m}^{-1}$ linear increase in EC in the soil solution.

The increase in EC and salt levels in the soil solution by applying CS and AS has been previously documented (Dunlop et al., 2019; Havlin et al., 1999; Machado et al., 2014; Mao et al., 2016; Vargas et al., 2015). However, many of these studies did not investigate the implications of application rates of CS and AS on the exchangeable cations in soils with high $\mathrm{Na}^{+}$content or those subjected to saline water irrigation, as in northeast Florida. The goal of this study is to raise awareness to the fact that management practices related to application of CS and some sources of fertilizer can exacerbate the salinity problem in the region. More specifically, the objective was to evaluate the effect of increased rates of $\mathrm{CS}$ and $\mathrm{AS}$ on soil $\mathrm{pH}, \mathrm{EC}$, and exchangeable cations in an agricultural soil with a high content of $\mathrm{Na}^{+}$.

\section{Materials and Methods}

\subsection{Selection of the Area of Study}

The main part of the study consisted of a soil incubation experiment conducted using soil samples from a commercial potato farm located in Hastings, FL, United States. The 200 ha farm has been under cultivation for more than 50 years, and the potato yields have decreased in some areas of the farm. The soil on this farm was 
classified as sandy loamy, siliceous, active, hyperthermic Alfic Alaquods belonging to Wabasso Fine Sand Series (Readle, 1983). Three areas, with low, medium, and high relative potato yield, were selected by the grower. The fields were irrigated with seepage. Composite soil samples from approximately 50 subsamples from each area were collected from the $0-20 \mathrm{~cm}$ soil depth layer during potato tuber initiation in Mar. 2012. The soil samples were homogenized, sieved $(2 \mathrm{~mm})$, and air-dried. The soil chemical characterization of the three production areas is presented in Table 1.

Table 1. Mean values of soil chemical characterization of $0-20$ soil depth layer using Mehlich- 1 and potato foliar analysis sampled from three different areas based on relative potato yield levels (low, medium and high). Samples were taken during tuber initiation at Hastings, FL, Mar. 2012

\begin{tabular}{|c|c|c|c|c|c|c|c|}
\hline Yield level & $\mathrm{EC}$ & $\mathrm{pH}$ & $\mathrm{Na}$ & $\mathrm{P}$ & $\mathrm{K}$ & $\mathrm{Ca}$ & $\mathrm{Mg}$ \\
\hline & $\mathrm{dS} \cdot \mathrm{m}^{-1}$ & & \multicolumn{3}{|c|}{-------------- mg·dm } & \multicolumn{2}{|c|}{----- $\mathrm{cmol}_{\mathrm{c}} \cdot \mathrm{dm}^{-3}$} \\
\hline \multicolumn{8}{|l|}{ Soil analysis ${ }^{z}$} \\
\hline Low & 3.79 & 5.94 & 252.9 & 358.3 & 167.5 & 7.83 & 1.26 \\
\hline Medium & 2.77 & 5.82 & 168.1 & 275.9 & 198.8 & 6.39 & 1.74 \\
\hline High & 1.49 & 5.39 & 31.7 & 290.9 & 117.1 & 6.96 & 1.46 \\
\hline \multirow[t]{2}{*}{ Yield level } & & & $\mathrm{N}$ & $\mathrm{P}$ & $\mathrm{K}$ & $\mathrm{Ca}$ & $\mathrm{Mg}$ \\
\hline & & & -------- & 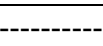 & $-\mathrm{mg} \cdot \mathrm{kg}^{-1}$ & ------- & ----- \\
\hline \multicolumn{8}{|c|}{ Potato foliar analysis ${ }^{\mathrm{y}}$} \\
\hline Low & & & 52460 & 5285 & 57797 & 12263 & 6398 \\
\hline Medium & & & 57191 & 4254 & 47145 & 11228 & 7279 \\
\hline High & & & 56475 & 3745 & 47868 & 9765 & 7626 \\
\hline Critical value & & & $<30000$ & $<2000$ & $<30000$ & $<6000$ & $<2500$ \\
\hline
\end{tabular}

Note. ${ }^{\mathrm{Z}} \mathrm{EC}$, soil electrical conductivity; soil $\mathrm{pH}$ in water; sodium $(\mathrm{Na})$; phosphorus $(\mathrm{P})$; potassium $(\mathrm{K})$; calcium $(\mathrm{Ca})$; magnesium $(\mathrm{Mg})$; nitrogen $(\mathrm{N}) .{ }^{\mathrm{y}}$ critical value for macronutrients for potatoes at first blossom (Hochmuth et al. (2018).

Thirty-five potato foliar tissue samples per area were collected following the procedure described by Stark and Westermann (2008) and sent to the University of Florida Analytical Research Laboratory in Gainesville, FL, for analysis of $\mathrm{N}$, phosphorus $(\mathrm{P}), \mathrm{Ca}$, potassium $(\mathrm{K})$, and $\mathrm{Mg}$. Based on the results of soil chemical characterization and plant analysis, the area with a low relative potato yield and a higher soil content of $\mathrm{Na}$ was chosen for the incubation study. After the potato harvest in Apr. 2012, 90 soil samples were collected from the 0-20 cm soil depth layer in a 40 ha area of the low potato production area and combined into a large composite sample. The soil was sieved $(2 \mathrm{~mm})$, homogenized, and air-dried. The incubation study was initiated immediately after soil was dried. The chemical characterization of the soil used in the incubation study is presented in Table 2.

Table 2. Mean values of the soil chemical characterization (Mehlich-1) of the $0-20 \mathrm{~cm}$ soil depth layer used in the incubation study collected from a "low potato yield level area" after tuber harvest at Hastings, FL, May 2012.

\begin{tabular}{|c|c|c|c|c|c|c|c|c|c|c|}
\hline \multicolumn{11}{|c|}{ Soil analysis and interpretation ${ }^{z, y}$} \\
\hline $\mathrm{pH}$ & $\mathrm{EC}$ & $\mathrm{Na}$ & $\mathrm{P}$ & K & $\mathrm{Zn}$ & $\mathrm{Mn}$ & $\mathrm{Ca}$ & $\mathrm{Mg}$ & CEC & V \\
\hline & $\mathrm{dS} \cdot \mathrm{m}^{-1}$ & 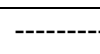 & --------- n & $\mathrm{dm}^{-3}$ & - & ------- & ------------- & $\mathrm{mol}_{\mathrm{c}} \cdot \mathrm{dm}^{-3}-$ & ----- & $\%$ \\
\hline 6.2 & 1.27 & 127.9 & 289.2 & 71.0 & 5.7 & 7.0 & 5.18 & 0.81 & 7.1 & 72.6 \\
\hline- & - & - & Very High & High & High & Medium & Very High & Very High & - & - \\
\hline
\end{tabular}

$\overline{\text { Note. }}{ }^{\text {z }}$ soil $\mathrm{pH}$ in water; soil electrical conductivity (EC); sodium (Na); phosphorus (P); potassium (K); zinc (Zn); manganese $(\mathrm{Mn})$; calcium $(\mathrm{Ca})$; magnesium $(\mathrm{Mg})$; $\mathrm{CEC}$, cation exchange capacity at $\mathrm{pH} 7$; $\mathrm{V}$, base saturation. ${ }^{\mathrm{y}}$ Interpretation of soil analysis reported by Hochmuth et al. (2018).

\subsection{Soil Incubation with Calcium Sulfate and Ammonium Sulfate}

The incubation of soil with CS and AS was conducted at the Horticultural Sciences Department of the University of Florida in Gainesville, FL. A subsample of $200 \mathrm{~g}$ of air-dried soil was incubated with 12 rates of CS $(100,200$, $400,600,800,1000,1400,1800,2200,2800,3400$, and $4000 \mathrm{~kg} \mathrm{ha}^{-1}$ of CS) and 12 rates of AS $(25,50,75,100$, 
$125,150,175,200,300,400,500$, and $600 \mathrm{~kg} \mathrm{ha}^{-1}$ of $\mathrm{N}$ ) and a unamended (control) treatment for each amendment in a single factorial experiment. All reagents used in this study were analytical grade of calcium sulfate dihydrate $\left(\mathrm{CaSO}_{4} \cdot 2 \mathrm{H}_{2} \mathrm{O}\right)(98 \%)$ and ammonium sulfate $\left[\left(\mathrm{NH}_{4}\right)_{2} \mathrm{SO}_{4}\right](99.5 \%)$ (Acros Organics, Thermo Fisher Scientific, Waltham, MA).

The CS and AS rate calculations were performed on a weight basis assuming a soil bulk density of $1 \mathrm{~g} \mathrm{~cm}^{-3}$. The experiment was layout was a completely randomized factorial design with 2 amendments and 12 rate rates with four replications. The soil samples were mixed with the respective CS and AS rates and placed into $250 \mathrm{~mL}$ glass containers. In the region, CS is broadcasted and then incorporated into the soil using disk harrow implement. Sources of $\mathrm{N}$ used for granular $\mathrm{N}$ fertilizer blend include ammonium nitrate $\left(\mathrm{NH}_{4} \mathrm{NO}_{3}\right)$ and $\left(\mathrm{NH}_{4}\right)_{2} \mathrm{SO}_{4}$. Granular fertilizer blends are generally banded or broadcasted, then incorporated into the soil using disk harrow at pre-plant or planting. Sidedress application of N can be applied as granular or liquid on the side of the potato hill and followed by the hilling operation using disk bedders. During the incubation, distilled water was periodically applied to maintain soil moisture equivalent to $60 \%$ of field capacity (FC). The internal temperature of the incubator was maintained at $25^{\circ} \mathrm{C}$. After 60 days of incubation, soil samples were removed from the containers and oven dried at $105{ }^{\circ} \mathrm{C}$ until constant weight. Samples were analyzed for $\mathrm{pH}$ in water in a 1:2.5 soil: water ratio. EC was analyzed using the soil saturated paste extraction method in a 1:1 soil:water ratio (U.S. Salinity Laboratory, 1954). Soil samples were also analyzed for $\mathrm{Na}, \mathrm{K}, \mathrm{Ca}, \mathrm{Mg}, \mathrm{Zn}$, and $\mathrm{Mn}$ according to Environmental Protection Agency (EPA) method 200.7 (US.EPA, 1994; Sparks et al., 1996) after extracting with Mehlich-1 (Mehlich, 1953).

\subsection{Statistical Analysis}

Data were analyzed using the PROC GLM and REG procedures of SAS (version 9.4; SAS Institute, Cary, NC) at the level of significance of $\mathrm{P} \leq 0.05$ for soil extractable nutrient after incubation. Pearson's linear correlations between all soil chemical attributes and CS and AS were performed using PROC CORR of SAS.

\section{Results and Discussion}

In the low potato yield area, the initial survey sampling taken during tuber initiation stage revealed a soil EC at $3.79 \mathrm{dS} \mathrm{m}^{-1}$ and $252.9 \mathrm{mg} \mathrm{dm}^{-3}$ of $\mathrm{Na}^{+}$, as well as high concentration of $\mathrm{P}, \mathrm{K}, \mathrm{Ca}$, and $\mathrm{Mg}$ in the $0-20 \mathrm{~cm}$ soil depth layer (Table 1). The plant tissue analysis (Table 1) confirmed that the three areas with various yields did not present any deficiencies related to N, P, K, Ca and Mg according to the critical levels reported by Hochmuth et al. (2018), which indicates that the low potato yield was likely due to high soil $\mathrm{EC}$ and $\mathrm{Na}^{+}$in the $0-20 \mathrm{~cm}$ soil depth layer. However, the levels of $\mathrm{Na}^{+}$in the plant and chloride $\left(\mathrm{Cl}^{-}\right)$in soil and plant were not evaluated in this study. Chloride toxicity could also have a played a role on the tuber yield reduction if present in high levels, despite the fact that high concentrations of $\mathrm{Na}^{+}$in the shoots can be primary driver of growth inhibition on potato compare to $\mathrm{Cl}^{-}$(Hutsh et al., 2019). Overall, the values of nutrients and $\mathrm{Na}^{+}$from the initial sampling were higher compared to the soil sampling performed after the potato harvest (Table 2), which was used for the incubation study. The lower nutrient concentration and soil EC in the $0-20 \mathrm{~cm}$ soil depth layer in the second sampling was attributed to the $98 \mathrm{~mm}$ of precipitation that occurred between samplings, the crop nutrient removal and the dilution of nutrients due to the mixing of soil from layers below $20 \mathrm{~cm}$ during the mechanical harvest. Nevertheless, the low yield area chosen for the soil incubation study with CS and AS still exhibited a considerable concentration of $\mathrm{Na}^{+}(127.9 \mathrm{mg} \mathrm{dm}$ ), which according to Sonon et al. (2015) would require an application of $4200 \mathrm{~kg} \mathrm{ha}^{-1}$ of CS to remove exchangeable $\mathrm{Na}^{+}$after irrigation with salt-free water.

The impacts of the increased application rates of $\mathrm{CS}$ on the soil $\mathrm{pH}$ after 60 days of incubation are presented in Figure 1A. Soil pH decreased from 6.2 to 5.9 during incubation for the treatments without any CS or AS amendment. The soil moisture was maintained in ideal conditions for microbial decomposition and mineralization of plant residues particles from harvest $(<2 \mathrm{~mm})$ which can contribute to the decrease in soil $\mathrm{pH}$ during the incubation period. There was a slight linear decrease in soil $\mathrm{pH}$ from 5.9 to 5.6 with the increasing rates of CS. The decreased soil $\mathrm{pH}$ corresponded to 0.063 units of $\mathrm{pH}$ for each $1000 \mathrm{~kg}$ of CS. The application of $\mathrm{CS}$ and its subsequent dissociation in the soil solution led to the formation of ion pairs between $\mathrm{SO}_{4}{ }^{-2}$ with $\mathrm{Ca}^{+2}$, $\mathrm{Mg}^{+2}, \mathrm{Na}^{+}$and aluminum $\left(\mathrm{Al}^{3+}\right)$, forming $\mathrm{CS}$, magnesium sulfate $\left(\mathrm{MgSO}_{4}\right)$, sodium sulfate $\left(\mathrm{Na}_{2} \mathrm{SO}_{4}\right)$ and aluminum sulfate $\left(\mathrm{Al}_{2}\left(\mathrm{SO}_{4}^{+}\right)_{3}\right)$, respectively, increasing the soil EC. Thus, the higher content of $\mathrm{Ca}^{+2}$ replace $\mathrm{Na}^{+}$ in the soil exchange sites (Zambrosi et al., 2007) as the application rates of CS increased resulting in a decline in soil pH (McTee et al., 2017; Qayyum et al., 2017; Vet et al., 2014). 

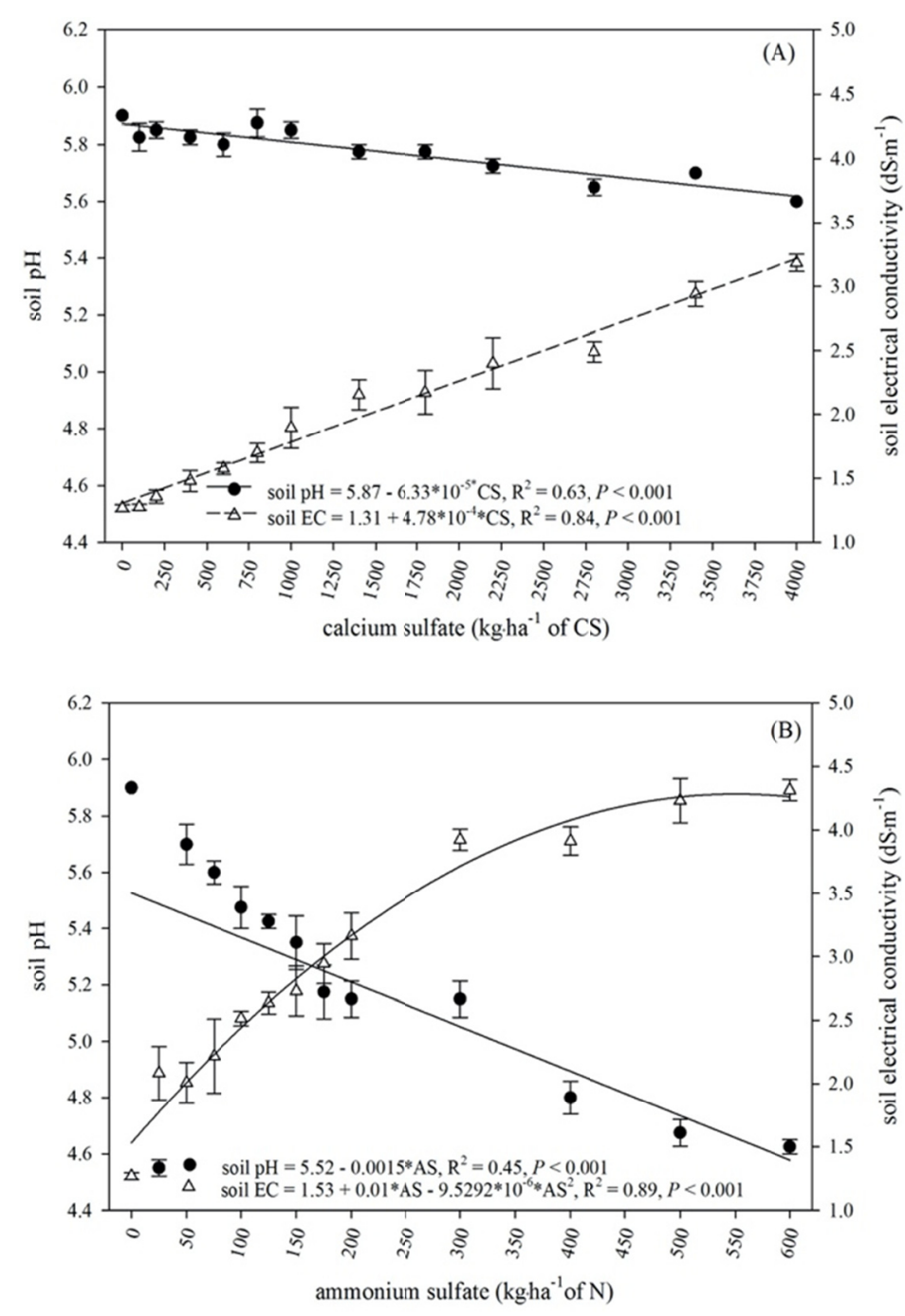

Figure 1. Soil pH and electrical conductivity (EC) influenced by different rates of A) calcium sulfate (CS) and B) ammonium sulfate (AS) after $60 \mathrm{~d}$ incubation period. $\mathrm{P}<0.001$ indicates that the regression equation and all coefficients are significant at $\mathrm{P}<0.001$ level. Error bars indicated standard deviation.

The inverse linear relationship between soil $\mathrm{pH}$ and increasing CS was also verified by the negative Pearson's correlation coefficient (Table 3). These results corroborate with the work of Mao et al. (2016) and Zhao et al. (2018a), in which flue gas desulfurization (FGD) gypsum was used for remediation and/or reclamation of saline-sodic soils. There was a significant decrease of 0.8-1.35 units of $\mathrm{pH}$ after 6 months of application of $15,000 \mathrm{~kg} \cdot \mathrm{ha}^{-1}$ of FGD-gypsum compared to the control treatment with no application of FGD-gypsum (Mao et al., 2016). In a long-term field study with initial soil $\mathrm{pH}$ ranging from 8.9 to 9.4, the application of FGD-gypsum reduced soil $\mathrm{pH}$ by $4.2 \%$ in the first year, $11.1 \%$ in the second year, and $14.6 \%$ in the third year (Zhao et al., 2018b). These authors suggested that the decrease in $\mathrm{pH}$ as a function of the CS application occurs in soils where $\mathrm{pH}$ is normally controlled by $\mathrm{HCO}_{3}{ }^{-}$and $\mathrm{CO}_{3}{ }^{2-}$ concentrations. The application of $\mathrm{CS}$ in those soils may lead to the precipitation of $\mathrm{Ca}$ with the above-mentioned anions resulting in the formation of calcium carbonate $\left(\mathrm{CaCO}_{3}\right)$ (Mao et al., 2016; Sakai et al., 2012). 
Table 3. Pearson's simple coefficient of correlation $(r)$ of rates of calcium sulfate (CS) and soil chemical parameters $(n=52)$

\begin{tabular}{|c|c|c|c|c|c|c|c|c|c|}
\hline & $\mathrm{pH}^{\mathrm{y}}$ & $\mathrm{EC}$ & $\mathrm{Na}$ & $\mathrm{Ca}$ & $\mathrm{Mg}$ & $\mathrm{K}$ & V & $\mathrm{Zn}$ & $\mathrm{Mn}$ \\
\hline CS & $-0.80^{* * * z}$ & $0.92^{* * *}$ & $0.68^{* * *}$ & $0.92^{* * *}$ & $0.58^{* * *}$ & $0.32^{*}$ & $0.64^{* * *}$ & $0.06^{\mathrm{ns}}$ & $0.05^{\mathrm{ns}}$ \\
\hline $\mathrm{pH}$ & & $-0.69^{* * *}$ & $-0.58^{* * *}$ & $-0.78^{* * *}$ & $-0.49^{* * *}$ & $-0.22^{\mathrm{ns}}$ & $-0.54^{* * *}$ & $-0.04^{\mathrm{ns}}$ & $0.03^{\mathrm{ns}}$ \\
\hline EC & & & $0.66^{* * *}$ & $0.83^{* * *}$ & $0.55^{* * *}$ & $0.39^{* *}$ & $0.64^{* * *}$ & $0.15^{\mathrm{ns}}$ & $0.07^{\mathrm{ns}}$ \\
\hline $\mathrm{Na}$ & & & & $0.82^{* * *}$ & $0.90^{* * *}$ & $0.72^{* * *}$ & $0.62^{* * *}$ & $0.36^{* *}$ & $0.28^{*}$ \\
\hline $\mathrm{Ca}$ & & & & & $0.80^{* * *}$ & $0.54^{* * *}$ & $0.70^{* * *}$ & $0.26^{\mathrm{ns}}$ & $0.22^{\mathrm{ns}}$ \\
\hline $\mathrm{Mg}$ & & & & & & $0.82^{* * *}$ & $0.58^{* * *}$ & $0.54^{* * *}$ & $0.49^{* * *}$ \\
\hline $\mathrm{K}$ & & & & & & & $0.51^{* * *}$ & $0.72^{* * *}$ & $0.70^{* * *}$ \\
\hline V & & & & & & & & $0.20^{\mathrm{ns}}$ & $0.20^{\mathrm{ns}}$ \\
\hline $\mathrm{Zn}$ & & & & & & & & & $0.71^{* * *}$ \\
\hline
\end{tabular}

Note. ${ }^{\mathrm{z}} \mathrm{ns}$, not significant; *, significant at $P \leq 0.05 ; * *$, significant at $P \leq 0.01 ; * * *$, significant at $P<0.001$. ${ }^{\mathrm{y}}$ soil $\mathrm{pH}$ in water; soil electrical conductivity $\left(\mathrm{EC}, \mathrm{dS} \mathrm{m}^{-1}\right)$; sodium $\left(\mathrm{Na}, \mathrm{mg} \mathrm{dm}^{-3}\right)$; potassium $\left(\mathrm{K}, \mathrm{mg} \mathrm{dm}^{-3}\right)$; zinc $\left(\mathrm{Zn}, \mathrm{mg} \mathrm{dm} \mathrm{dm}^{-3}\right)$; manganese $\left(\mathrm{Mn}, \mathrm{mg} \mathrm{dm} \mathrm{d}^{-3}\right)$; calcium $\left(\mathrm{Ca}, \mathrm{cmol}_{\mathrm{c}} \mathrm{dm}^{-3}\right)$; magnesium $\left(\mathrm{Mg}, \mathrm{cmol}_{\mathrm{c}} \mathrm{dm}^{-3}\right)$; base saturation $(\mathrm{V}, \%)$.

The soil EC is dependent on the concentration of electrolytes (Nadler \& Frenkel, 1980) and this phenomenon corroborated with the linear increase in soil EC with the increasing rates of CS (Figure 1A). The $\mathrm{Ca}^{2+}$ in soil solution can replace the $\mathrm{Na}^{+}$in the exchange complex, forming salts with high solubility as $\mathrm{Na}_{2} \mathrm{SO}_{4}$ and $\mathrm{MgSO}_{4}$, which would be prone to leaching if conditions permit (Ali et al., 2007). The increase in EC as a function of CS application corroborates with the study conducted by Chun et al. (2001). The authors applied four doses of FGD-gypsum, 0; 5800; 11600; and $23100 \mathrm{~kg} \mathrm{ha}^{-1}$ in a saline-sodic soil and the corresponded increase in soil EC was $0.5 ; 0.75 ; 1.2$ and $1.3 \mathrm{dS} \mathrm{m}^{-1}$, respectively.

The effects of increased application rates of AS on the soil $\mathrm{pH}$ and EC are presented in Figure 1B. The AS has high acidifying potential (Wang et al., 2018), which would invariably reduce soil $\mathrm{pH}$. In contrast to CS, the application of AS significantly reduced soil $\mathrm{pH}$ from 5.9 to near 4.6 resulting in a significant negative linear response (Figure 1B). Under the soil moisture conditions of the incubation, the AS was dissociated and ammonium $\left(\mathrm{NH}_{4}{ }^{+}\right)$became present in the soil solution. Under field conditions, $\mathrm{NH}_{4}{ }^{+}$may be absorbed by plants, or depending on the soil moisture and temperature conditions, it can be subject to nitrification (e.g., conversion of $\mathrm{NH}_{4}^{+}$to nitrate $\left(\mathrm{NO}_{3}{ }^{-}\right)$). However, the nitrification releases $\mathrm{H}^{+}$into the soil solution, which results in soil acidification (Hart et al., 2013; Havlin et al., 1999; Wang et al., 2018). In the present study under controlled conditions, the significant decrease in soil $\mathrm{pH}$ with the increased application rates of AS was largely due to the nitrification process, which also affected other soil chemical attributes, such as EC, base saturation, and exchangeable $\mathrm{Na}, \mathrm{Mg}$, $\mathrm{Zn}$ and $\mathrm{Mn}$ (Table 4).

Table 4. Pearson's simple coefficient of correlation $(r)$ of rates of ammonium sulfate (AS) and soil chemical parameters $(n=52)$

\begin{tabular}{|c|c|c|c|c|c|c|c|c|c|}
\hline & $\mathrm{pH}^{\mathrm{y}}$ & EC & $\mathrm{Na}$ & $\mathrm{Ca}$ & $\mathrm{Mg}$ & K & V & $\mathrm{Zn}$ & $\mathrm{Mn}$ \\
\hline AS & $-0.67^{* * * z}$ & $0.90^{* * *}$ & $0.56^{* * *}$ & $0.51^{* * *}$ & $0.63^{* * *}$ & $0.46^{* * * *}$ & $-0.68^{* * * *}$ & $0.45^{* * *}$ & $0.94^{* * *}$ \\
\hline $\mathrm{pH}$ & & $-0.68^{* * *}$ & $-0.41^{* *}$ & $-0.70^{* * *}$ & $-0.72^{* * *}$ & $-0.58^{* * *}$ & $0.76^{* * *}$ & $-0.36^{* *}$ & $-0.70^{* * *}$ \\
\hline EC & & & $0.65^{* * *}$ & $0.51^{* * *}$ & $0.66^{* * *}$ & $0.47^{* * *}$ & $-0.69^{* * *}$ & $0.48^{* * *}$ & $0.85^{* * *}$ \\
\hline $\mathrm{Na}$ & & & & $0.66^{* * *}$ & $0.85^{* * *}$ & $0.77^{* *}$ & $-0.30^{*}$ & $0.71^{* * *}$ & $0.64^{* * *}$ \\
\hline $\mathrm{Ca}$ & & & & & $0.94^{* * *}$ & $0.96^{* * *}$ & $-0.31^{*}$ & $0.71^{* * *}$ & $0.64^{* * *}$ \\
\hline $\mathrm{Mg}$ & & & & & & $0.95^{* * *}$ & $-0.43^{* *}$ & $0.77^{* * *}$ & $-0.75^{* * *}$ \\
\hline $\mathrm{K}$ & & & & & & & $-0.21^{\mathrm{ns}}$ & $0.80^{* * *}$ & $0.63^{* * *}$ \\
\hline V & & & & & & & & $-0.16^{\mathrm{ns}}$ & $-0.58^{* * *}$ \\
\hline $\mathrm{Zn}$ & & & & & & & & & $0.63^{* * *}$ \\
\hline
\end{tabular}

Note. ${ }^{\mathrm{z}} \mathrm{ns}$, not significant; ${ }^{*}$, significant at $P \leq 0.05 ;{ }^{* *}$, significant at $P \leq 0.01 ; * * *$, significant at $P<0.001$. ${ }^{\mathrm{y}}$ soil $\mathrm{pH}$ in water; soil electrical conductivity $\left(\mathrm{EC}, \mathrm{dS} \mathrm{m}^{-1}\right)$; sodium $\left(\mathrm{Na}, \mathrm{mg} \mathrm{dm}^{-3}\right)$; potassium $\left(\mathrm{K}, \mathrm{mg} \mathrm{dm}^{-3}\right)$; zinc $\left(\mathrm{Zn}, \mathrm{mg} \mathrm{dm} \mathrm{d}^{-3}\right)$; manganese $\left(\mathrm{Mn}, \mathrm{mg} \mathrm{dm} \mathrm{d}^{-3}\right)$; calcium $\left(\mathrm{Ca}, \mathrm{cmol}_{\mathrm{c}} \mathrm{dm}^{-3}\right)$; magnesium $\left(\mathrm{Mg}, \mathrm{cmol}_{\mathrm{c}} \mathrm{dm}^{-3}\right)$; base saturation $(\mathrm{V}, \%)$. 
There was a quadratic increase in the soil EC with increasing application rates of AS (Figure 1B). Raising the soil EC was due to the release of $\mathrm{NH}_{4}{ }^{+}$into the solution as a result of the dissolution of AS raising the salt content in the soil and lowering the soil pH (Bohn et al., 1985, Khonje et al., 1989). Figure 2 illustrates the release of $\mathrm{Na}^{+}$into the soil solution and a decrease of soil $\mathrm{pH}$.

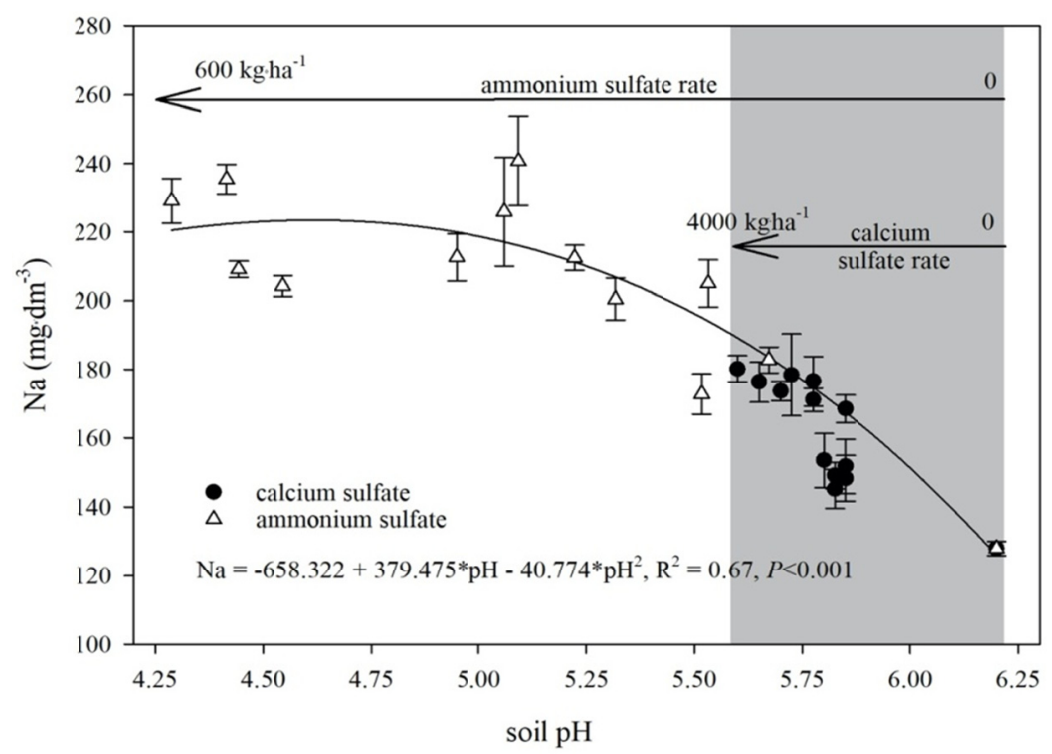

Figure 2. Mehlich-1 soil extractable sodium $\left(\mathrm{Na}^{+}\right)$as a function of soil $\mathrm{pH}$ impacted by combinations of calcium sulfate (CS) and ammonium sulfate (AS) applications after 60 -days incubation period. $\mathrm{P}<0.001$ indicates that the regression equation and all coefficients are significant at $\mathrm{P}<0.001$ level.

Error bars indicated standard deviation

Potato is considered sensitive to high soil EC. Ayers and Westcot (1994) determined that soil EC values of 3.8 dS $\mathrm{m}^{-1}$ determined by the soil paste extraction method (U.S. Salinity Laboratory, 1954) can reduce the yield potential of potato crop by $25 \%$. According to Metternicht and Zinck (1997), the variation in the soil EC class ranges between categories of non-saline, slightly saline, moderately saline, strongly saline, and very strongly saline with values of soil $\mathrm{EC}<4,4$ to 8,8 to 16,16 to 32 , and $>32 \mathrm{dS} \mathrm{m}^{-1}$, respectively. In the present study, the initial soil EC of $1.27 \mathrm{dS} \mathrm{m}^{-1}$ linearly increased to $3.2 \mathrm{dS} \mathrm{m}^{-1}$ with CS and quadratically increased peaking at 4.1 $\mathrm{dS} \mathrm{m}^{-1}$ with AS. The soil was initially classified as non-saline and became moderately saline after AS application rates above $350 \mathrm{~kg} \mathrm{ha}^{-1}$ of $\mathrm{N}$. Considering the usual CS rates adopted by growers is in the range of 896-2240 kg $\mathrm{ha}^{-1}$, these rates can potentially elevate the soil EC from 1.27 to $1.7-2.45 \mathrm{dS} \mathrm{m}^{-1}$ causing up to $10 \%$ potato crop yield loss (Ayers \& Westcot, 1994).

Figure 2 combines the overall range of soil $\mathrm{pH}$ as result of the incubation rates of $\mathrm{CS}$ and AS and their effects on soil extractable $\mathrm{Na}^{+}$. Soil $\mathrm{pH}$ lowered from 5.9 to 5.5 with the increasing rates of CS, whereas the application of AS further decreased soil $\mathrm{pH}$ to 4.6. As a result of acidification of the soil, there was a quadratic increase in the concentration of extractable $\mathrm{Na}^{+}$in the soil. The displacement of this cation was due to a release or increase in $\mathrm{H}^{+}$in response to the nitrification process, which also causes bases with lower valence to be exchanged for $\mathrm{H}^{+}$in the soil solution ( $\mathrm{Li}$ et al., 2000).

The original level of $\mathrm{Ca}$ in the soil pre-incubation was $5.18 \mathrm{cmol}_{\mathrm{c}} \mathrm{dm}^{-3}$, which is classified as very high (Liu et al., 2018). Extractable $\mathrm{Ca}$ in the soil solution increased significantly with the increase in CS rates due to the application of $\mathrm{Ca}$ (Figure 3A). The increase in $\mathrm{Ca}$ in soil after CS application has been previously reported (Mao et al., 2016; Zhao et al., 2018a). These authors also associated the increase in $\mathrm{Ca}$ with the decrease of $\mathrm{Na}^{+}$in the soil, after the substitution of $\mathrm{Na}^{+}$by $\mathrm{Ca}^{2+}$ in the soil exchange sites and subsequent $\mathrm{Na}$ leaching. Extractable $\mathrm{Ca}$ also increase for the increasing application of AS, however, it was not significant (Figure 3B). 

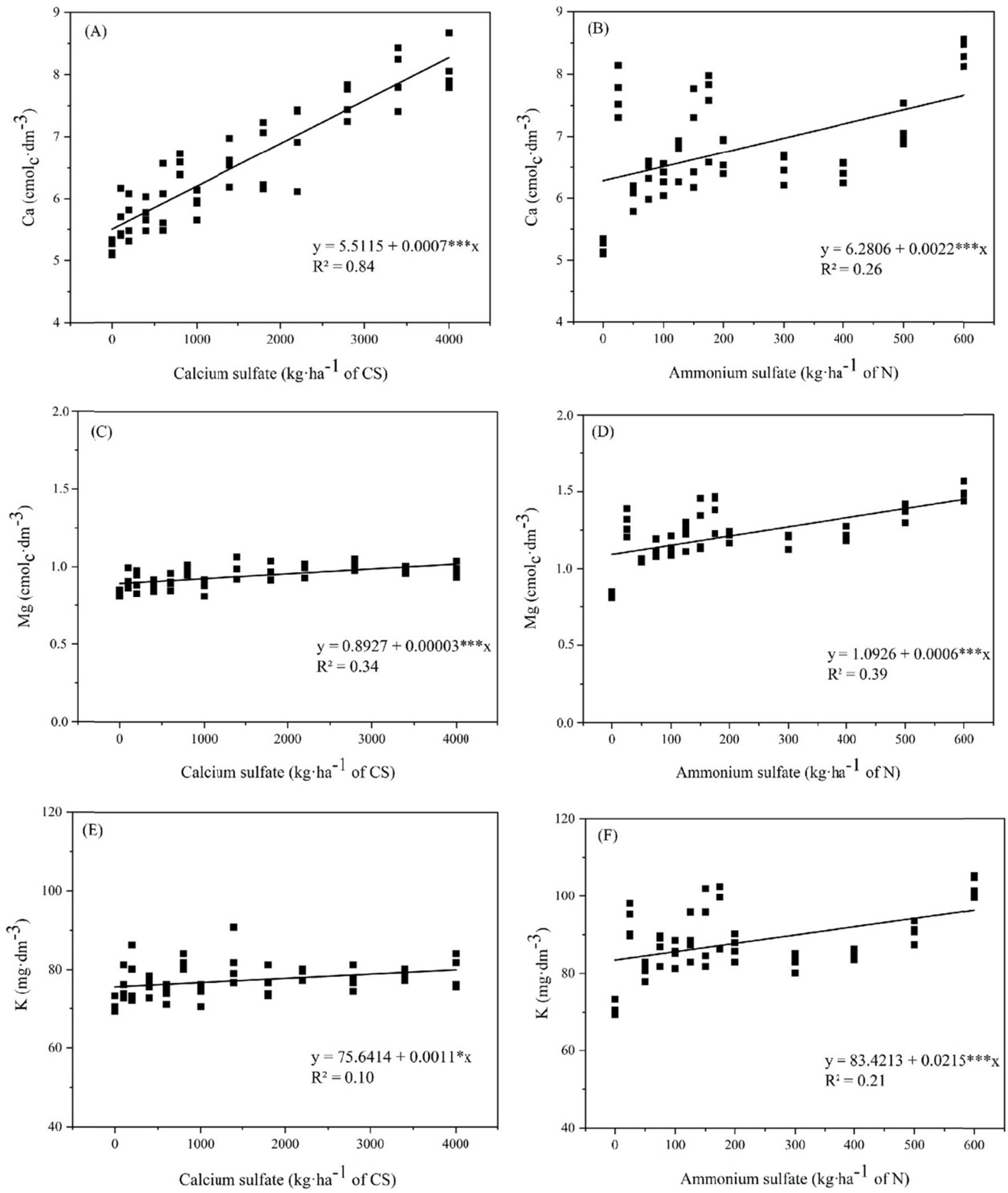

Figure 3. Mehlich-1 soil extractable calcium $(\mathrm{Ca})(\mathrm{A}, \mathrm{B})$, magnesium $(\mathrm{Mg})(\mathrm{C}, \mathrm{D})$, and potassium $(\mathrm{K})(\mathrm{D}, \mathrm{E})$ impacted by the application of different rates of calcium sulfate (CS) (A, B, E) and ammonium sulfate (AS) (B, $\mathrm{D}, \mathrm{F}){ }^{*}$, significant at $P<0.05 ; * * *$, significant at $P<0.001$

There was no change in Mg levels with the application of CS (Figure 3C). When applying AS, the soil pH ranged between 5.9 and 5.5 but the variation in the soil $\mathrm{Mg}$ content was not significant and was similar to the treatment with CS. However, when analyzing the entire range of the $\mathrm{pH}$ curve of AS, which was approximately 5.9 to 4.6, there was a linear increase in concentration of $\mathrm{Mg}$ with the decrease in soil $\mathrm{pH}$, resulting in displacement of the $0.5 \mathrm{cmol}_{\mathrm{c}} \mathrm{dm}^{-3} \mathrm{Mg}$ to the soil solution (Figure 3D). As for K, neither the application with CS or AS nor the variation of soil $\mathrm{pH}$ affected $\mathrm{K}$ concentration in the soil solution (Figures 3D and $3 \mathrm{E}$ ). 
The overall changes in the soil percent base saturation with the application of CS and AS are presented in Figure 4. The use of CS caused significant linear increase in the soil percent base saturation, which was expected with the increase in available $\mathrm{Ca}^{2+}$ in the soil solution. Conversely, the increasing application of AS rates promoted a linear reduction of soil percent base saturation due to the decrease in soil pH (Bertossi et al., 2016; Guimarães et al., 2015; Matias et al., 2015; Mendonça et al., 2017).
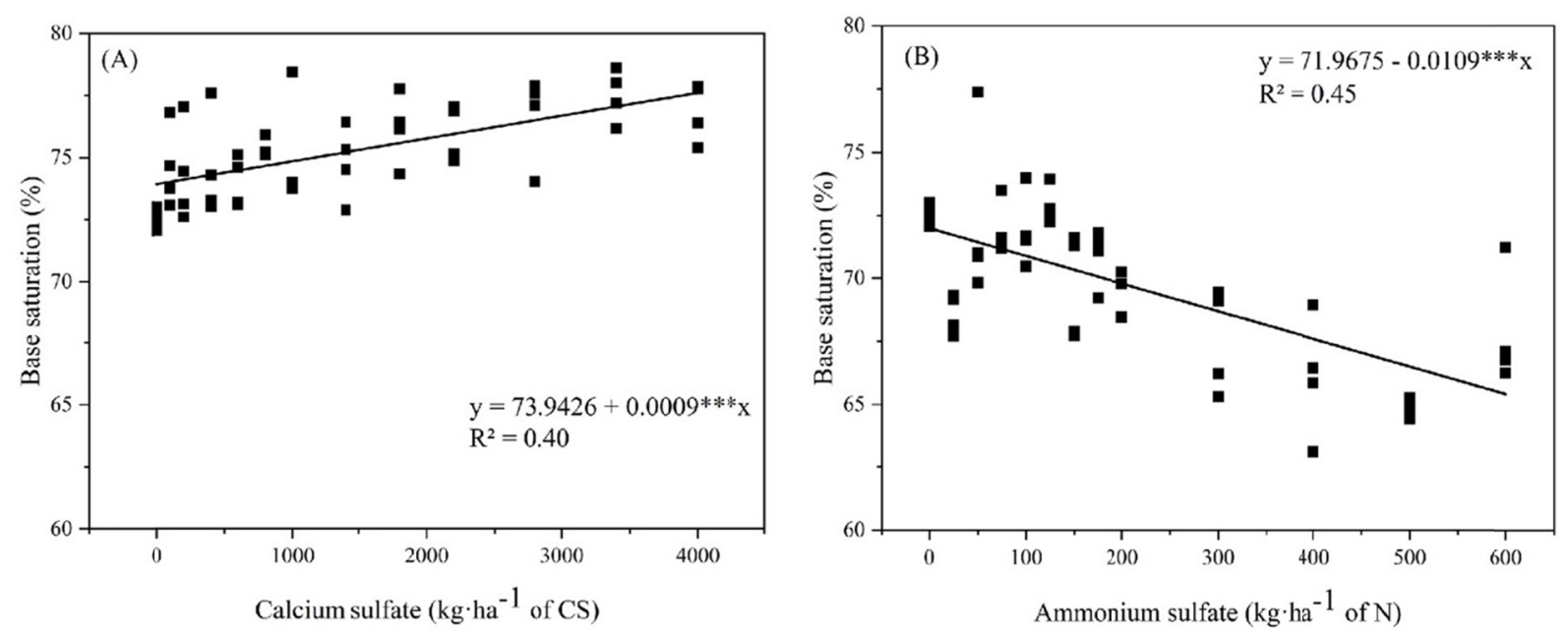

Figure 4. Soil percent base saturation (V) as affected by the application of increasing rates of calcium sulfate (CS)

(A) and ammonium sulfate (AS) (B). ***, significant at $P<0.001$

The influence of $\mathrm{pH}$ on the concentration of extractable micronutrients in the soil, as a function of CS and AS application, was also evaluated. The change in soil $\mathrm{pH}$ from 6.2 to 5.5 resulted in no differences in the concentration of micronutrients in the soil solution with the application of CS (Figures 5A and 5C). However, when soil $\mathrm{pH}$ decreased below 5.5 with the application of $\mathrm{AS}$, the concentration of both $\mathrm{Zn}$ and Mn in the soil solution increased significantly (Figures 5B and 5D). Overall, the concentration of the cationic micronutrients, such as Zn, increased with decreasing soil pH (Luna et al., 2016; Udeigwe et al., 2016). Similar results were observed by McBride and Blasiak (1979), who worked with $\mathrm{Zn}$ and $\mathrm{Cu}$ solubility in variable ranges of soil $\mathrm{pH}$. The authors described that the adsorption of $\mathrm{Zn}^{2+}$ in low soil $\mathrm{pH}$ can be reduced and the solubility of $\mathrm{Zn}$ increases in the soil solution. Typically, at high soil $\mathrm{pH}$, micronutrients such as $\mathrm{Zn}$ and $\mathrm{Mn}$ are in the oxidized forms as zinc oxide $(\mathrm{ZnO})$ and manganese oxide $(\mathrm{MnO})$, respectively, forms in which plants are not capable of uptake because of their insolubility in the soil solution (Wei et al., 2006). Thus, the effect of acidification caused by the application of AS may be beneficial for increasing the solubility of micronutrients $\mathrm{Zn}$ and Mn in the soil. 

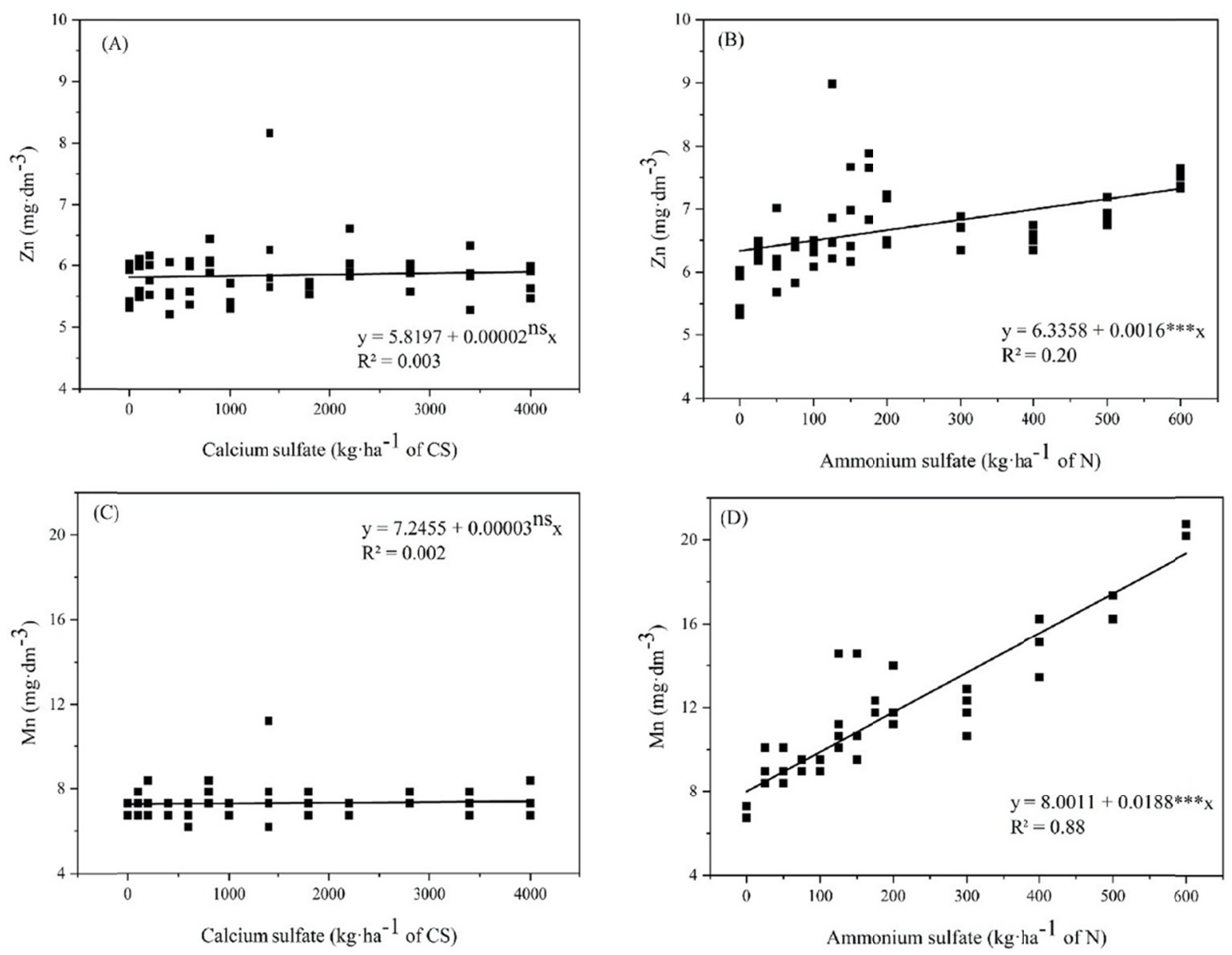

Figure 5. Mehlich-1 soil availability of zinc $(\mathrm{Zn})(\mathrm{A}, \mathrm{B})$ and manganese $(\mathrm{Mn})(\mathrm{C}, \mathrm{D})$ due to the application of different rates of calcium sulfate $(\mathrm{CS})(\mathrm{A}, \mathrm{C})$ and ammonium sulfate $(\mathrm{AS})(\mathrm{B}, \mathrm{D}) .{ }^{\mathrm{ns}}$, not significant; ***, significant at $P<0.001$

\section{Conclusions}

The soil incubation with CS and AS was conducted under controlled conditions and do not exactly replicate the open field conditions. Results from the incubation study indicate that the application of CS rates resulted in a small decreased in soil $\mathrm{pH}$ and in a linear increase in soil EC to levels that could further exacerbate the negative effect of salts on crop yield. Thus, the use of large rates of CS for consecutive years may further impair soil conditions for cropping due to the seasonal high EC of the irrigation water. Results from the incubation study showed that applications of AS can effectively reduce the soil $\mathrm{pH}$, increase soil EC and concentration of extractable $\mathrm{Na}$ in the soil solution. Ordinary AS application rates between 50 to $150 \mathrm{~kg} \mathrm{ha}^{-1}$ of $\mathrm{N}$ can potentially elevate soil EC from $1.5 \mathrm{dS} \mathrm{m}^{-1}$ to 1.9 and $2.8 \mathrm{dS} \mathrm{m}^{-1}$, respectively. Conversely, the acidification of the soil solution due to the AS application will increase the concentration of extractable $\mathrm{Zn}$ and $\mathrm{Mn}$. The results from the incubation study illustrate the "potential effect" of fertilizer and CS application rates in the soil EC, $\mathrm{pH}, \mathrm{Na}$ and nutrient concentration in the rootzone, which in some circumstances can negatively impact crop growth and yield. The selection of low-saline fertilizers and split fertilizer applications are strategies that can help mitigate the impact of fertilizer in the soil EC, especially in areas with high salt content in irrigation wells. Thus, the need of CS should be carefully determined based on the existing exchangeable $\mathrm{Ca}$ and soil $\mathrm{pH}$ from soil testing, while $\mathrm{N}$ fertilizer rates should be determined based on crop nutrient removal and potential tuber yield.

\section{Acknowledgments}

We are grateful for the contribution and support of the northeast Florida vegetable and potato growers. We would like to acknowledge the staff of the University of Florida, Hastings Agricultural Extension Center, Hastings, FL; Scott Taylor, Marcelo Paranhos, Scott Chambers, David Dinkins, Mark Warren, and Patrick Moran for their assistance with sampling and sample analysis. 


\section{References}

Ali, M. A., Lee, C. H., \& Kim, P. J. (2007). Effect of phosphor-gypsum on reduction of methane emission from rice paddy soil. Korean Journal of Environmental Agriculture, 26, 131-140. https://doi.org/10.5338/ KJEA.2007.26.2.131

Ayers, R., \& Westcot, D. (1994). Water quality for agriculture: FAO Irrigation and Drainage Paper Number 29. Retrieved July 9, 2019 from http://www.fao.org/docrep/003/T0234E/T0234E03.htm\#ch2.4.3

Barlow, P. M. (2003). Ground water in freshwater-saltwater environments of the Atlantic Coast (US Geological Survey Circular 1262). https://doi.org/10.3133/cir1262

Bertossi, A. P. A., Júnior, P. R. R., Ribeiro, P. H., Menezes, J. P. C., Cecílio, R. A., \& Andrade, F. V. (2016). Soil cover and chemical and physical attributes in oxisol in the Atlantic forest biome. Revista Árvore, 40, 219-228. https://doi.org/10.1590/0100-67622016000200004

Bohn, H. L., McNael, B. L., \& O’Connor, G. A. (1985). Soil chemistry (2nd ed.). New York, Chichester. https://doi.org/10.1002/jpln.19861490315

Chun, S., Nishiyama, M., \& Matsumoto, S. (2001). Sodic soils reclaimed with by-product from flue gas desulfurization: Corn production and soil quality. Environmental Pollution, 114, 453-459. https://doi.org/ 10.1016/S0269-7491(00)00226-8

Da Silva, A. L. B. R., Hashiguti, H. T., Zotarelli, L., Miglaccio, K. W., \& Dukes, M. D. (2018). Soil water dynamics of shallow water table soils cultivated with potato crop. Vadose Zone Journal, 17, 1-15. https://doi.org/10.2136/vzj2018.04.0077

Dukes, M. D., Zotarelli, L., \& Morgan, K. T. (2010). Use of irrigation technologies for vegetable crops in Florida. HortTechnology, 20, 133-142. https://doi.org/10.21273/HORTTECH.20.1.133

Dunlop, G., Palanichamy, J., Kokkat, A., James, E. J., \& Palani, S. (2019). Simulation of saltwater intrusion into coastal aquifer of Nagapattinam in the lower cauvery basin using SEAWAT. Groundwater for Sustainable Development, 8, 294-301. https://doi.org/10.1016/j.gsd.2018.11.014

Ferreira, C. J. B., Zotarelli, L., Tormena, C. A., Rens, L. R., \& Rowland, D. L. (2017). Effects of water table management on least limiting water range and potato root growth. Agricultural Water Management, 186, 1-11. https://doi.org/10.1016/j.agwat.2017.02.020

Frazee, Jr. J., \& McClaugherty, D. R. (1979). Investigation of ground water resourses and salt water intrusion in the coastal areas of northeast Florida (St. Johns River Water Management District, Technical Publication SJ 80-4, p. 129). https://doi.org/10.1007/698_2017_190

Guimarães, C. C., Floriano, E. P., \& Vieira, F. C. B. (2015). Chemical constraints to initial growth of Eucalyptus saligna in sandy soils of Pampa Gaúcho: A case study. Ciência Rural, 45, 1183-1190. https://doi.org/ $10.1590 / 0103-8478 \mathrm{cr} 20120533$

Hart, J. M., Sullivan, N. P., Anderson, A. G., Hulting, D. A., \& Chistensen, N. W. (2013). Soil acidity in Oregon: Understanding and using concepts for crop production. Oregon State University Extension Service 9061. Oregon State University, Corvallis, OR. Retrieved July 9, 2019 from https://catalog.extension.oregonstate. edu/em9061

Havlin, J. L., Beaton, J. D., Tisdale, S. L., \& Nelson, W. L. (1999). Soil fertility and fertilizers: An introduction to nutrient management (6th ed.). Prentice Hall, Upper Saddle River, N.J.

Hochmuth, G. J., Maynard, D., Vavrina, C., Hanlon, E., \& Simonne, E. H. (2018). Plant tissue analysis and interpretation for vegetable crops in Florida. IFAS HS964. Gainesville: University of Florida Institute of Food and Agricultural Sciences. Retrieved August 8, 2019 from https://edis.ifas.ufl.edu/ep081

Khonje, D. J., Varsa, E. C., \& Klubek, B. (1989). The acidulation effects of nitrogenous fertilizers on selected chemical and microbiological properties of soil. Communications in Soil Science and Plant Analysis, 20, 1377-1395. https://doi.org/10.1080/00103628909368156

Hütsch, B. W., Keipp, K., Glaser, A. K., \& Schubert, S. (2018). Potato plants (Solanum tuberosum L.) are chloride-sensitive: Is this dogma valid? Journal of the Science of Food and Agriculture, 98, 3161-3168. https://doi.org/10.1002/jsfa.8819

Li, L. Y., \& Li, R. S. (2000). The role of clay minerals and the effect of $\mathrm{H}^{+}$ions on removal of heavy metal $\left(\mathrm{Pb}^{2+}\right)$ from contaminated soils. Canadian Geotechnical Journal, 37, 296-307. https://doi.org/10.1139/t99-106 
Liao, X., Su, Z., Liu, G., Zotarelli, L., Cui, Y., \& Snodgrass, C. (2016). Impact of soil moisture and temperature on potato production using seepage and center pivot irrigation. Agricultural Water Management, 165, 230-236. https://doi.org/10.1016/j.agwat.2015.10.023

Liao, X., Liu, G., Hogue, B., \& Li, Y. (2015). Phosphorus availability and environmental risks in potato fields in North Florida. Soil Use and Management, 31, 308-312. https://doi.org/10.1111/sum.12186

Liu, G. D., Simonne, E. H., Morgan, K. T., \& Hochmuth, G. J. (2018). Soil and fertilizer management for vegetable production in Florida. IFAS HS711. Gainesville: University of Florida Institute of Food and Agricultural Sciences. Retrieved August 14, 2019 from http://edis.ifas.ufl.edu/cv101

Luna, D. F., Aguirre, A., Pittaro, G., Bustos, D., Ciacci, B., \& Taleisnik, E. (2016). Nutrient deficiency and hypoxia as constraints to Panicum coloratum growth in alkaline soils. Grass and Forage Science, 72, 640-653. https://doi.org/10.1111/gfs.12263

Machado, R. M. A., Bryla, D. R., \& Vargas, O. (2014). Effects of salinity induced by ammonium sulfate fertilizer on root and shoot growth of highbush blueberry. Acta Horticulturae, 1017, 407-414. https://doi.org/ 10.17660/ActaHortic.2014.1017.49

Mao, Y., Li, X., Dick, W. A., \& Chen, L. (2016). Remediation of saline-sodic with flue gas desulfurization gypsum in a reclaimed tidal flat of southeast China. Journal of Environmental Science, 45, $224-232$. https://doi.org/10.1016/j.jes.2016.01.006

Matias, S. S. R., Nóbrega, J. C. A., Nóbrega, R. S. A., Andrade, F. R., \& Baptistel, A. C. (2015). Spatial variability of soil chemical properties of Latosol (Oxisol) cultivated conventionally with Glycine max in the cerrado of the Piauí State. Revista Agroambiente, 9, 17-26. https://doi.org/10.5327/Z1982-84702015000 12036

McBride, M. B., \& Blasiak, J. J. (1979). Zinc and copper solubility as a function of pH in an acid soil. Soil Science Society of America Journal, 43, 866-870. https://doi.org/10.2136/sssaj1979.036159950043000 50009x

McTee, M. R., Lekberg, Y., Bullington, L., Rummel, A., Mummey, D. L., Ramsey, P. W., \& Hinman, N. W. (2017). Restoring ecological properties of acidic soils contaminated with elemental sulfur. Science of The Total Environment, 587-588, 449-456. https://doi.org/10.1016/j.scitotenv.2017.02.110

Metternicht, G., \& Zinck, J. A. (1997). Spatial discrimination of salt- and sodium-affected soil surfaces. International Journal Remote Sensing, 18, 2571-2586. https://doi.org/10.1080/014311697217486

Mehlich, A. (1953). Determination of $\mathrm{P}, \mathrm{Ca}, \mathrm{Mg}, \mathrm{K}, \mathrm{Na}, \& \mathrm{NH}_{4}$ by North Carolina soil testing laboratories. North Carolina Soil Test Div., North Carolina Department of Agriculture, Raleigh.

Mendonça, B. A. F., Filho, E. I. F., Schaefer, C. E. G. R., Mendonça, J. G. F., \& Vasconcelos, B. N. F. (2017). Soil-vegetation relationships and community structure in a "terra-firme"-whitesand vegetation gradient in Viruá National Park, northern Amazon, Brazil. Anais da Academia Brasileira de Ciências, 89, 1269-1293. https://doi.org/10.1590/0001-3765201720160666

Nadler, A., \& Frenkel, H. (1980). Determination of soil solution electrical conductivity from bulk soil electrical conductivity measurements by the four-electrode method. Soil Science Society of America Journal, 44, 1216-1221. https://doi.org/10.2136/sssaj1980.03615995004400060017x

Palta, J. P. (1996). Role of calcium in plant responses to stresses: linking basic research to the solution of practical problems. HortScience, 31, 51-57. https://doi.org/10.21273/HORTSCI.31.1.51

Qayyum, M. F., Rehman, M. Z., Ali, S., Rizwan, M., Naeem, A., Maqsood, M., ... Ok, Y. S. (2017). Residual effects of monoammonium phosphate, gypsum and elemental sulfur on cadmium phytoavailability and translocation from soil to wheat in an effluent irrigated field. Chemosphere, 174, 515-523. https://doi.org/10.1016/j.chemosphere.2017.02.006

Readle, E. L. (1983). Soil survey of St. Johns County, Florida. Washington, D.C.

Sakai, Y., Matsumoto, S., \& Sadakata, M. (2012). Alkali soil reclamation with flue gas desulfurization gypsum in China and assessment of metal content in corn grains. Soil and Sediment Contamination, 13, 65-80. https://doi.org/10.1080/10588330490269840

Silva, G. H., Chase, R. W., Hammerschmidt, R., Vitosh, M. L., \& Ktchen, R. B. (1991). Irrigation, nitrogen and gypsum effects on specific gravity and internal defects of Atlantic potatoes. American Potato Journal, 68, 751-765. https://doi.org/10.1007/BF02853806 
Sparks, D. L., Page, A. L., Helmke, P. A., Loeppert, R. H., Soltanpour, P. N., Tabatabai, M. A., ... Semner, M. E. (1996). Methods of Soil Analysis, Part 3-Chemical Methods (SSSA Book series No. 5). Madison, WI. https://doi.org/10.2136/sssabookser5.3

Sonon, L.S., Saha, U., \& Kissel, D. E. (2015). Soil salinity. Testing, data interpretation and recommendations. Circular 1019 (p. 6). University of Georgia, USA. Retrieved February 10, 2019, from https://secure.caes.uga.edu/extension/publications/files/pdf/C\%201019_3.PDF

Spechler, R. M. (1994). Saltwater intrusion and quality of water in the Floridan aquifer system, northeastern Florida: US Geological Survey. Water-Resources Investigations Report 92-4174 (p. 71). Retrieved December 15, 2019, from https://pubs.er.usgs.gov/publication/wri924174

Stark, J., \& Westermann, D. (2008). Managing potato fertility. In D. A. Johnson (Ed.), Potato Health Management (pp. 55-66). The American Phytopathology Society, St. Paul, MN.

Udeigwe, T. K., Eichmann, M., Eze, P. N., Ogendi, G. M., Morris, M. N., \& Riley, M. R. (2016). Copper micronutrient fixation kinetics and interactions with soil constituents in semi-arid alkaline soils. Soil Science and Plant Nutrition, 62, 289-296. https://doi.org/10.1080/00380768.2016.1197046

U.S. EPA. (1994). Method 200.7: Determination of metals and trace elements in water and wastes by inductively coupled plasma-atomic emission spectrometry (Revision 4.4). Cincinnati, $\mathrm{OH}$.

U.S. Salinity Laboratory. (1954). Diagnoses and Improvement of Saline and Alkali Soils; Agriculture Handbook (No. 60). USDA, Washington, DC.

Vargas, O. L., \& Bryla, D. R. (2015). Growth and fruit production of highbush blueberry fertilized with ammonium sulfate and urea applied by fertigation or as granular fertilizer. HortScience, 50, 479-485. https://doi.org/10.21273/HORTSCI.50.3.479

Vet, R., Artz, R. S., Carou, S., Shaw, M., Ro, C. U., Aas, W., ... Hou, A. (2014). A global assessment of precipitation chemistry and deposition of sulfur, nitrogen, sea salt, base cations, organic acids, acidity and pH, and phosphorus. Atmospheric Environment, 93, 3-100. https://doi.org/10.1016/j.atmosenv.2013.10.060

Wang, X., Liu, S., Zhang, S., Li, H., Maimaitiali, B., Feng, G., \& Rengel, Z. (2018). Localized ammonium and phosphorus fertilization can improve cotton lint yield by decreasing rhizosphere soil $\mathrm{pH}$ and salinity. Field Crops Research, 217, 75-81. https://doi.org/10.1016/j.fcr.2017.12.011

Wei, X., Shao, M., Hao, M., \& Gale, W. J. (2006). Changes in soil properties and the availability of soil micronutrients after 18 years of cropping and fertilization. Soil and Tillage Research, 91, 120-130. https://doi.org/10.1016/j.still.2005.11.009

Xiao, H., Wang, D., Medeiros, S. C., Bilskie, M. V., Hagen, S. C., \& Hall, C. R. (2019). Exploration of the effects of storm surge on the extent of saltwater intrusion into the surficial aquifer in coastal east-central Florida (USA). Science of the Total Environment, 648, 1002-1017. https://doi.org/10.1016/j.scitotenv.2018. 08.199

Yarney, E. Y. (2017). Temporal and spatial variability of agricultural irrigation water salinity and effects of irrigation and drainage practices on soil salinity in northeast Florida (Doctoral dissertation, University of Florida, Gainesville, USA).

Zambrosi, F. C. B., Alleoni, L. R. F., \& Caires, E. F. (2007). Gypsum application and ionic speciation of the solution from an Oxisol under no-till system. Ciência Rural, 37, 110-117. https://doi.org/10.1590/ S0103-84782007000100018

Zhao, Y., Wang, S., Li, Y., Liu, J., Zhuo, Y., Chen, H., ... Sun, Z. (2018a). Extensive reclamation of saline-sodic soils flue gas desulfurization gypsum on the Songnen Plain, Northeast China. Geoderma, 321, 52-60. https://doi.org/10.1016/j.geoderma.2018.01.033

Zhao, Y., Wang, S., Li, Y., Liu, J., Zhuo, Y., Zhang, W., ... Xu, L. (2018b). Long-term performance of flue gas desulfurization gypsum in a large-scale application in a saline-alkali wasteland in northwest China. Agriculture, Ecosystems \& Environment, 261, 115-124. https://doi.org/10.1016/j.agee.2018.01.009 


\section{Copyrights}

Copyright for this article is retained by the author(s), with first publication rights granted to the journal.

This is an open-access article distributed under the terms and conditions of the Creative Commons Attribution license (http://creativecommons.org/licenses/by/4.0/). 